p-ISSN. 2086-9029

e-ISSN. 2654-5675

Vol. 22 No. 2, HIm. 159-352, Desember 2020

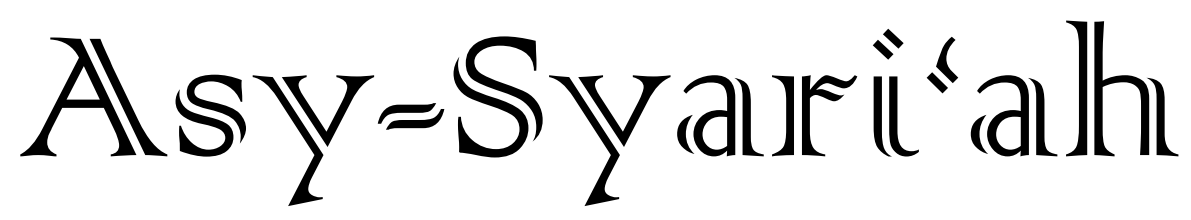

- Implementasi Prinsip Keadilan dalam Hukum Perjanjian Syari'ah

$(159-178)$ Zaenudin Mansyur

- Akad Rahn Tasyjili pada Gadai Tanah Pertanian di Pegadaian Syariah

$(179-196)$ Rahmadi Indra Tektona, Dyah Ochtorina Susanti

- Potensi Sertifikasi Halal dalam Mengahadapi Masyarakat Ekonomi

$(197-218)$ ASEAN

Deviana Yuanitasari, Helitha Noviana Dewi

- Akad Mudharabah sebagai Instrumen Pendanaan dan Pembiayaan di

$(219-236)$ Lembaga Keuangan Syariah

Asep Dadang Hidayat, Moh. Sar'an

- Praktik Rekayasa Dispensing Pump SPBU Persfektif Peraturan

$(237-258)$ Perundang-Undangan dan Hukum Islam

Hazar Kusmayanti, Ratu Chairunissa

- Dinamika Penerapan Akad Syariah dalam Produk Keuangan di Bank

$(259-274)$ Syariah

Jaenudin

- Etika Bisnis Islam pada Perilaku Pemasaran dan Kepuasan Konsumen

$(275-290)$ Wida Ramdania

- Kebijakan Fiskal Islam pada Masa Al-Khilafah Al-Islamiyah

Supriatna, Dedah Jubaedah

- Pelanggaran Prinsip Tanggungjawab Perusahaan Asuransi Investasi Persfektif Perundang-Undangan dan Hukum Ekonomi Syariah

Yoghi Arief Susanto, Yeti Sumiyati

- Identifikasi Kebutuhan Pembiayaan Syariah Peternak Lembu di Deli (337-352) Serdang

Marlya Fatira AK, Anriza Witi Nasution, Tuti Kurnia

FACULTY OF SHARIA AND LAW

STATE ISLAMIC UNIVERSITY SUNAN GUNUNG DJATI BANDUNG-INDONESIA IN COLLABORATION WITH ASOSIASI SARJANA SYARIAH INDONESIA 


\section{Asy-Syari'ah}

Volume 22, Number 2, 2020

\section{EDITOR-IN-CHIEF}

Ine Fauzia

\section{EDITORIAL BOARD}

Sofyan al-Hakim, UIN Sunan Gunung Djati Bandung, Indonesia Deni Kamaludin Yusup, UIN Sunan Gunung Djati Bandung, Indonesia

Meria Utama, Fakultas Hukum Univrsitas Sriwijaya, Indonesia

Dewi Mayaningsih, UIN Sunan Gunung Djati Bandung, Indonesia

Andrey Sujatmiko, Fakultas Hukum Universitas Trisakti, Jakarta, Indonesia

Hetty Hassanah, Universitas Komputer Indonesia, Indonesia

Tarun Ghawana, CDMS, New Delhi, India

Muhammad Hasanuddin, UIN Sunan Gunung Djati Bandung, Indonesia

Syahrul Anwar, UIN Sunan Gunung Djati Bandung, Indonesia

Aden Rosadi, UIN Sunan Gunung Djati Bandung, Indonesia

\section{PEER-REVIEWERS}

S. Salahudin Suyurno, Universiti Teknologi MARA (UiTM) Melaka, Malaysia

Ezani Yaakub, Universiti Teknologi MARA (UiTM) Malaysia, Malaysia

Zezen Zaenal Mutaqin, University of California, Los Angeles, United States

Muhammad Irfan Helmy, IAIN Salatiga, Semarang, Indonesia

Ahmad Ali Nurdin, UIN Sunan Gunung Djati Bandung

Tajul Arifin, UIN Sunan Gunun Djati Bandung, Indonesia

Mohamad Anton Athoillah, UIN Sunan Gunung Djati Bandung, Indonesia

Renny Supriyatni, Universitas Padjadjaran, Indonesia

Ahmad Tholabi Karlie, UIN Syarif Hidayatullah Jakarta, Indonesia

Ija Suntana, UIN Sunan Gunung Djati Bandung, Indonesia

Ahmad Fathonih, UIN Sunan Gunung Djati Bandung, Indonesia

Fauzan Ali Rasyid, UIN Sunan Gunung Djati Bandung, Indonesia

Rahman Syamsuddin, Universitas Islam Negeri Alauddin Makassar, Indonesia

\section{PROOFREADER/DESIGN COVER}

Nanang Sungkawa

\section{LAYOUT EDITOR}

Opik Rozikin

Asy-Syari'ah has been accredited by The Ministry of Education and Cultere, Republic of Indonesia as an academic journal in Sinta 3 (SK Diirjen Penguatan Riset dan Pengembangan Kemristekdikti No. 14/E/KPT/2019), valid for 5 years from Volume 19 No. 1 Tahun 2017 until Volume 23 No. 2 Tahun 2022. 


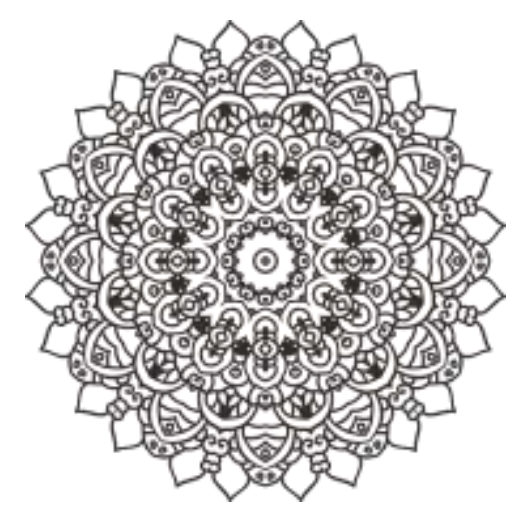

\title{
AKAD MUDHARABAH SEBAGAI INSTRUMEN PENDANAAN DAN PEMBIAYAAN DI LEMBAGA KEUANGAN SYARIAH
}

\author{
${ }^{1}$ Asep Dadang Hidayat, ${ }^{2}$ Mohamad Sar'an \\ ${ }^{1}$ STAI Al-Mushdariyah, Bandung, ${ }^{2}$ UIN Sunan Gunung Djati Bandung \\ E-mail: adhidayat.uin@gmail.com, saranmohamad@gmail.com
}

\begin{abstract}
Islamic financial institutions grow and develop in Indonesia in line with regulations issued by the government after the promulgation of Law no. 21 of 2008 concerning Islamic Banking. This study aims to discuss the Mudharabah Instrument agreement as Funding and Financing in Islamic Financial Institutions. This research includes using normative juridical methods and qualitative approaches. Data sources refer to books, documents, and other relevant written sources. The results of this study indicate that although mudharabah is not explicitly presented in the Al-Qur'an and AsSunnah, most of the scholars are considered as the operational foundation of Islamic financial institutions. However, the development of the Mudharabah Akad Concept in Islamic Financial Institutions is still needed by the concept of modern economic development.
\end{abstract}

Keywords: Financial Institutions Syari'ah; Mudharabah Agreement; Mudharib; Shahib Al-Maal 
Abstrak: Lembaga keuangan syariah tumbuh dan berkembang di Indonesia sejalan dengan regulasi yang dikeluarkan oleh pemerintah setelah diundangkannya UndangUndang No. 21 Tahun 2008 tentang Perbankan Syariah. Penelitian ini bertujuan untuk membahas akad mudharabah sebagai Instrumen Pendanaan dan Pembiayaan di Lembaga Keuangan Syariah. Penelitian ini termasuk padamenggunakan metode yuridis normatif dan pendekatan kualitatif. Sumber data mengacu kepada buku, dokumen dan sumber tertulis lainnya yang relevan. Hasil penelitian ini menunjukkan bahwa meskipun mudharabah tidak disebut secara eksplisit dalam Al-Qur'an dan As-Sunnah, namun sebagian besar ulama menjadikannya sebagai landasan operasional di Lembaga keuangan Syariah. Namun demikian pengembangan Konsep Akad mudharabah di Lembaga Keuangan Syariah masih terus diperlukan sesuai dengan pengembangan konsep ekonomi modern.

Kata-Kata Kunci: Akad; Mudharabah; Pendanaan; Pembiayaan; Lembaga Keuangan Syari'ah 


\section{Pendahuluan}

Salah satu pembeda lembaga keuangan syariah dengan lembaga keuangan konvensional adalah diaplikasikannya produk berbasis bagis hasil musyarakah dan mudharabah. Selain mudharabah terdapat produk-produk lainnya seperti murabahah ${ }^{1}$, hiwalah ${ }^{2}$, dan rahn atau gadai ${ }^{3}$ yang lebih banyak diminati oleh para nasabah. Sehingga peran mudharabah di bank syari'ah dan lembaga keuangan syari'ah lainnya, sampai saat ini belum bisa di implementasikan secara optimal dalam melakukan pengembangan ekonomi syari'ah, kondisi tersebut terjadi karena masih terdapat hal-hal yang menjadi kendala yang harus dihadapi dalam upaya memaksimalkan akad mudharabah di lembaga keuangan syari'ah. ${ }^{4}$

Hukum Islam yang diasumsikan sebagai aturan yang sakral dan religius, maka sering dipahami bahwa hukum Islam sebagai hukum yang statis abadi. Pada waktu yang bersamaan adaptabilitas dari hukum yang menjadi tuntutan perubahan sosial merupakan tantangan yang senantiasa harus dihadapi hukum Islam, dimana konsep-konsep dan pranata-pranata hukum seringkali dipengaruhi oleh dampak perubahan sosial tersebut. Dalam sektor keuangan, selama dua dasawarsa terakhir hukum Islam dapat menjadi alternatif terhadap krisis keuangan yang terjadi di dunia, seiring bergeraknya perubahan sosial yang adaptip, hukum Islam terus bertahan menjadi penunjuk bagi umat Islam. ${ }^{5}$

Lembaga keuangan syariah yang menerapkan suatu sistem bebas bunga (interestfree), kini cukup mendapat perhatian dari masyarakat luas terlebih perhatian dari umat Islam, sehingga di Indonesia pertumbuhan lembaga keuangan syariah cukup menggembirakan. Islam dengan norma-normanya yang menjadi rahmat bagi seluruh alam, dapat menjadi solusi sebuah keadilan, suka-sama suka, dan kejujuran dalam hal pencapaian dari sebuah tujuan. Lahirnya bank syari'ah yang kini sudah mempunyai payung hukum yang pasti yaitu Undang-Undang No. 21 Tahun 2008 tentang Perbankan Syariah, hal ini semakin menguatkan posisinya dan semakin berkembang produk-produk yang ditawarkannya.

Ada dua alasan utama yang mendasari berdirinya lembaga keuangan (perbankan) yang menerapkan sistem profit and loss sharing atau bagi hasil; pertama, bank konvensional yang menerapkan sistem bunga (interest), dipandang oleh agama khususnya agama Islam bahwa bunga itu hukumnya haram; kedua, sistem perbankan konvensional, dalam

\footnotetext{
${ }^{1}$ Murabahah adalah Jual beli barang pada harga asal dengan tambahan keuntungan yang disepakati.

${ }^{2}$ Sri Sudiarti, Fiqh Muamalah Kontemporer, "Hiwalah adalah pengalihan utang, baik berupa hak untuk mengalihkan pembayaran atau kewajiban untuk mendapatkan pembayaran utang, dari orang yang mempunyai utang dan piutang dengan disertai rasa percaya dan kesepakatan bersama."

${ }^{3}$ Menurut Iman Syafi'i, Gadai menjadikan suatu benda sebagai jaminan untuk utang, dimana utang tersebut bisa dilunasi (dibayar) dari benda (jaminan)

${ }^{4}$ Neneng Nurhasanah, Optimalisasi Peran Mudharabah Sebagai Salah Satu Akad Kerjasama Dalam Pengembangan Ekonomi Syari'ah. FH.UNISBA. VOL. XII. NO. 3 November 2010

${ }^{5}$ Sofian Al hakim, Dinamika Fatwa Mudharabah dan Murabahah di Indonesia dan Malaysia, (Bandung: Pusat Penelitian dan Penerbitan UIN Sunan Gunung Djati Bandung, 2019), hlm.1-2
} 
jangka panjang dapat menimbulkan penumpukan kekayaan pada sebagian kecil orang yaitu mereka yang memiliki kapital besar. ${ }^{6}$

Aplikasi mudharabah di lembaga keuangan syariah dalam dua bentuk funding (pendanaan) dan financing (pembiayaan) Mudharabah merupakan bentuk kerjasama antara dua pihak, dimana pihak kesatu penyedia dana (shahib al-maal) berani bertaruh mengambil resiko terhadap usaha yang dilaksanakan/dikerjakan oleh mudharib atau pihak yang mengelola dana sesuai dengan yang disepakati, sehingga atas resiko itu penyedia dana (shahib al-maal) berhak untuk mendapat bagi hasil/laba yang diperoleh dari usaha yang lakukan oleh pengelola dana/modal (mudharib). Mudharabah merupakan instrumen keuangan yang dapat menjadi bagian dalam memperluas lapangan usaha dan penyediaan lapangan kerja, meningkatkan tarap hidup, memberikan kontribusi terhadap pertumbuhan ekonomi dan juga dapat memeratakan pendapatan yang disesuaikan atas dasar prestasi. ${ }^{7}$

Mudharabah dengan sistem bagi hasil akan tercipta suatu kondisi yang harmonis dan dinamis, dimana masing-masing pihak senantiasa akan saling memperhatikan atas maju mundurnya kegiatan usaha yang dijalankan. Ada beberapa sistem bagi hasil yang dapat dijalankan yaitu; musyarakah ${ }^{8}$, mudharabah $^{9}$, muzara $^{\prime} h^{10}$ dan musaqa $h^{11}$.

Dengan merujuk kepada hal-hal yang sudah diuraikan di atas, maka fokus masalah yang menjadi pembahasan dalam tulisan ini adalah mudharabah dalam tinjauan fiqh dan penerapan mudharabah di lembaga keuangan syari'ah. Dengan harapan tulisan ini dapat memberikan kontribusi dalam khazanah keilmuan khususnya yang berkaitan dengan mudharabah.

\section{Metodologi}

Penelitian ini bermaksud untuk menguraikan implementasi mudharabah di lembaga keuangan syari'ah. Metode penelitian ini adalah studi kepustakaan. . Metode ini adalah cara yang digunakan untuk mengumpulkan data atau sumber yang berkaitan dengan topik yang dibahas, yang terdapat pada dokumen, jurnal atau buku atau dari internet dan pustaka. Data yang berkaitan dengan masalah mudharabah dalam tinjauan figh dan penerapan mudharabah di lembaga keuangan syari'ah ini dikumpulkan dengan

\footnotetext{
${ }^{6}$ Rahman Ambo Masse, Konsep Mudharabah Antara Kajian Fiqh dan Penerapan Perbankan, Jurnal Hukum Diktum, Volume 8, Nomor 1, Januari 2010

${ }^{7}$ Neneng Nurhasanah, Optimalisasi Peran Mudharabah Sebagai Salah Satu Akad Kerjasama Dalam Pengembangan Ekonomi Syari'ah. FH.UNISBA. VOL. XII. NO. 3 November 2010

${ }^{8}$ Menurut Rachmat Syafei, Fikih Muamalah, musyarakah adalah "Percampuran, yakni bercampurnya salah satu dari dua harta dengan harta lainnya, tanpa dapat dibedakan dari keduanya."

${ }^{9}$ Mudharabah akan dibahas secara khusus.

${ }_{10}$ Menurut Ulama Hanabilah dalam Fikih Muamalah (Rachmat Syafei) Muzara'ah adalah "Menyerahkan tanah kepada orang yang akan bercocok tanam atau mengelolanya, sedangkan tanaman (hasilnya) tersebut dibagi diantara keduanya."

${ }^{11}$ Menurut Wahbah Al-Juhaili, Al-Fiqh Al-Islamy wa 'Adillatuh, Musaqah adalah suatu akad dengan memberikan pohon kepada penggarap agar dikelola dan hasilnya dibagi diantara keduanya.
} 
cara yang sistimatis dengan berupaya memperhatikan keaktualannya dan ketepatannya. ${ }^{12}$

\section{Akad Mudharabah Sebagai Instrumen Pendanaan dan Pembiayaan di Lembaga Keuangan Syariah}

Menurut Wahbah Az-Zuhaili³: Al-dharb yang menjadi asal kata dari mudharabah memiliki arti secara harfiah yaitu memukul atau bisa juga diartikan berjalan. Diartikan memukul atau diartikan berjalan adalah dimaksudkan terhadap seseorang dalam proses menjalankan suatu usaha dengan memukulkan kakinya.

Secara bahasa mudharabah menurut Syeikh Abdurrahman Al-Juzairi" : merupakan ungkapan yang digunakan untuk penyerahan harta seseorang kepada yang lain untuk dikelola menjadi usaha agar keduanya (pemilik dana/modal dan pengelola) mendapat keuntungan yang telah disepakati oleh keduanya, dan jika mengalami kerugian menjadi tanggungan pemilik dana/modal. Mudharabah merupakan pecahan dari kata dharb yang berarti bepergian karena biasanya usaha dagang dilakukan dengan perjalanan. Dinamai pula qiradh atau muqaradhah yang asal katanya dari qardh yang diartikan dengan kata memotong, karena yang memiliki modal harus memotong dari sebagian harta miliknya untuk dijadikan usaha dengan imbalan mendapat bagian dari keuntungan, dan pengelola pun memotong sebagian dari keuntungannya untuk diberikan kepada pemilik dana/ modal sebagai hasil dari usahanya.

Menurut para ahli fikih, mudharabah sebagai suatu perjanjian di antara dua orang atau dua pihak dengan transaksi salah seorang menyerahkan harta miliknya kepada yang lain untuk dijadikan usaha dengan kompensasi mendapat imbalan bagian tertentu yang bersifat umum dari keuntungan seperti mendapat bagian setengah, sepertiga dan lain sebagainya disertai syarat-syarat yang khusus.

Madzhab Hanafi mendefinisikan, mudharabah ialah suatu akad untuk bagi hasil dari keuntungan yang diperoleh, dengan modal dari pihak pertama dan pengelolaan usaha oleh pihak kedua. Akan tetapi keadaan pengelola itu berbeda-beda sehingga bisa mempengaruhi hukum mudharabah.

Menurut madzhab Maliki, mudharabah atau qiradh dalam syar'i ialah suatu akad untuk mewakilkan modal yang ada pada pemilik dana/modal kepada yang lainnya untuk dijadikan usaha, dengan bentuk modal khusus yaitu uang emas atau perak yang biasa dipakai transaksi, dan pemilik dana/modal mesti menyerahkan dana kepada pengelola sesuai dengan yang dia inginkan untuk dijadikan usaha dengan segera.

\footnotetext{
${ }^{12}$ Sugiyono, Metode Penelitian Kuantitatif kualitatif dan R\&D, (Bandung: Alfabeta, 2008), 402. Lihat juga M. Nazir, Metode Penelitian (Jakarta: Ghalia Indonesia, 1983), 2.

${ }^{13}$ Wahbah Az-Zuhaili, Fiqih Islam Wa Adillatuhu, Jilid 5 (Jakarta: Gema Insani, 2011), 476.

${ }^{14}$ Syaikh Abdurrahman Al-Juzairi, Fikih Empat Madzhab, Jilid 4, (Jakarta: Pustaka Al-kautsar, 2015), 
Menurut madzhab Asy-Syafi'i, mudharabah atau qiradh itu ialah suatu akad yang berisi penyerahan dana seseorang kepada yang lain utuk dijadikan usaha dengan kompensasi dari kedua belah pihak tadi masing-masing mendapat bagian dari keuntungan dengan syarat-syarat khusus.

Menurut madzhab Hambali, mudharabah itu ialah sebuah ungkapan untuk penyerahan modal tertentu dari pemilik dana/modal yang diambil dari harta miliknya sendiri kepada orang yang akan menjalankan usaha, dengan konpensasi mendapat bagian tertentu yang bersifat umum dari keuntungan yang didapat, dan modal itu harus berupa mata uang resmi. Seperti halnya penyerahan dana, bisa juga dengan titipan kepada seseorang kemudian dikatakan kepadanya: "Bekerjalah dengan uang yang dititipkan tersebut secara mudharabah." sehingga mudharabah menurut mereka seperti halnya titipan.

Dari penjelasan-penjelasan di atas, penulis menyimpulkan: pertama, mudharabah merupakan suatu kesepakatan antara pemilik dana/modal (shahib al-maal) dengan pengelola dana/modal ('amil/mudharib); kedua, pemilik dana/modal (shahib al-maal) menyerahkan dana sepenuhnya kepada pengelola ('amil/mudharib) untuk diberdayakan; ketiga, keuntungan yang didapat dari hasil usaha tersebut dibagi bersama dengan porsi (nisbah) sesuai kesepakatan pada saat akad; keempat, jika adanya kerugian karena kesalahan atau kelalaian pihak pengelola ('amil/mudharib), maka akibat kerugian tersebut ditanggung bersama oleh kedua belah pihak, sedangkan apabila bukan diakibatkan karena kelalaian pihak pengelola ('amil/mudharib), maka kerugian sepenuhnya ditanggung oleh pemilik dana/modal (shahib al-maal).

Skema, proses mudharabah.

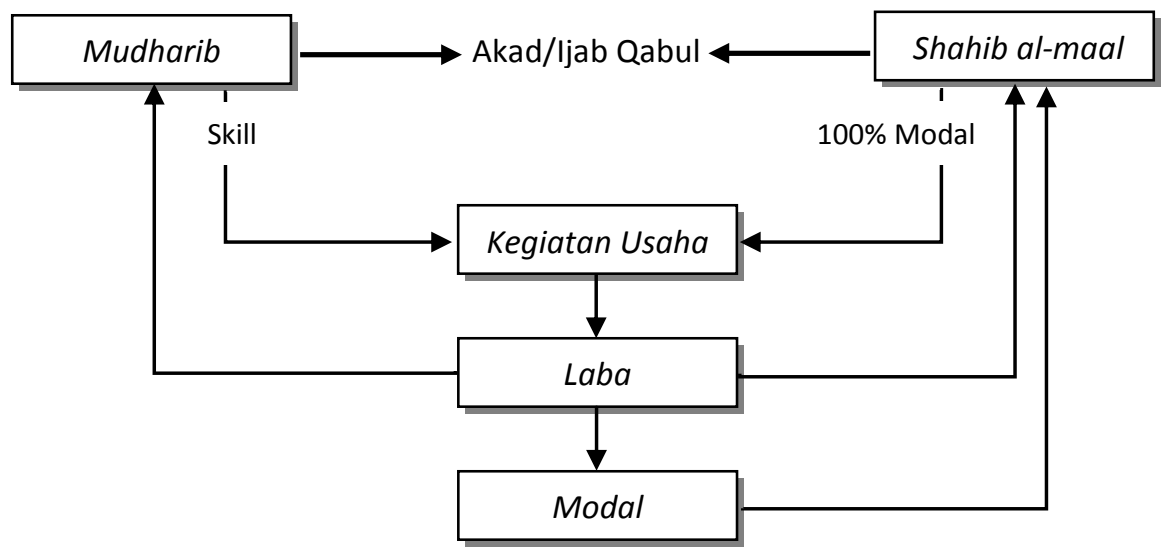

Gambar 1. Skema Proses Mudharabah 
Sebagai landasan hukum yang menjadi kesepakatan para ulama fiqih, bahwa disyari'atkannya mudharabah adalah Al-Qur'an, Hadits, ljma' dan Qiyas. ${ }^{15}$ Meskipun di dalam ayat-ayat Al-Qur'an tidak secara eksplisit menyatakan tentang mudharabah sebagai suatu bentuk muamalah, tetapi maksudnya menyiratkan dibolehkannya mudharabah. Oleh para ulama dijadikan sebagai landasan hukum mudharabah, ayat-ayat yang dimaksud adalah: Q.S. Al-Muzzammil (73): 20, Q.S. Al-Jumu'ah (62):10, Q.S. Al-Baqarah (2): 198, dan juga O.S. An-Nisa' (4): 29, Q.S. Al-Ma'idah (5): 1 serta Q.S. Al-Baqarah (2): $283 .{ }^{16}$

Firman Allah dalam Al-Qur'an Surat An-Nisa' ayat 29 :

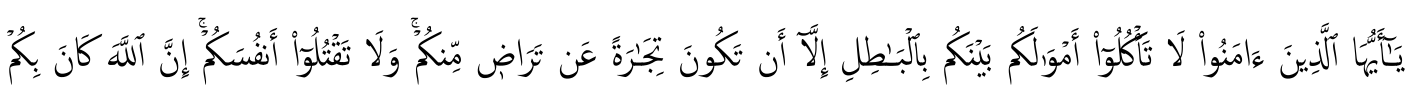

Didalam ayat itu Allah menegaskan kepada orang beriman agar dalam menjalankan perniagaannya tidak ada unsur paksaan, tetapi didasari dengan rasa suka, dan Allah melarang untuk saling makan harta antar sesama dengan cara yang batil.

Hadits Nabi Saw. yang berhubungan dengan mudharabah di antaranya:

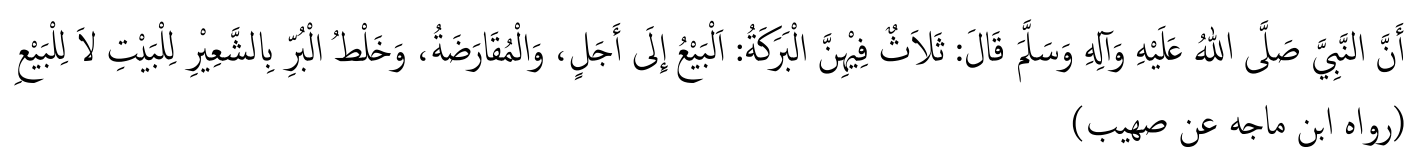

Hadits riwayat Ibnu Majah tersebut, mengemukakan bahwa keberkahan terdapat di dalam tiga perkara, ketiga perkara tersebut yaitu; pertama, jual beli yang pembayarannya dengan tempo (semacam kredit tanpa bunga); kedua, muqaradlah atau disebut juga dengan mudharabah; ketiga, dicampurkannya gandum (burr) dengan jemawut (syair) untuk keperluan rumah tangga tidak untuk dijual.

Dalam hadits yang diriwayatkan oleh Ath-Thabrani dari Ibnu Abbas r.a., bahwa Abbas bin Abdul Muthalib menetapkan syarat-syarat tertentu kepada mudharib pada saat beliau akan menyerahkan dana investasi. Diantara syarat tersebut yaitu beliau melarang mudharib untuk menyebrangi lautan, melarang mudharib untuk menuruni lembah dan melarang mudharib membelanjakan binatang ternak. Syarat yang diajukan oleh Abbas tersebut dibenarkan oleh Rasulullah SAW.

Sedangkan ljma' yang menjadi dasar mudharabah di antaranya "Para shahabat, tidak menentang atas perbuatan jama'ah dari kalangan shahabat yang pada saat itu melakukan kegiatan mudharabah dengan menggunakan harta anak yatim. ${ }^{\prime 17}$

Mudharabah di qiyaskan kepada "al-musaqah. Mudharabah dapat menjadi jembatan antara orang-orang kaya yang tidak pandai dalam mengelola hartanya untuk diusahakan,

\footnotetext{
${ }^{15}$ Rahmat Syafei, Fiqih Muamalah, (Bandung: CV Pustaka Setia, 2001), h.224.

${ }^{16}$ Lihat Fatwa Dewan Syariah Nasional-Majelis Ulama Indonesia No: 115/DSN-MUI/IX/2017 tentang Akad Mudharabah, Bagian Mengingat, angka 1, huruf a, b dan c.

${ }^{17}$ Sri Sudiarti, Fiqh Muamalah Kontemporer, (Medan: FEBI UIN-SU Press, 2018), 163
} 
dengan orang-orang yang memiliki keterbatasan harta tetapi mau bekerja dan memiliki kemampuan dalam usaha, sehingga dengan mudharabah dapat menjadi solusi untuk memenuhi kebutuhan kedua kelompok tersebut dan akan tercapainya kemaslahatan. ${ }^{1{ }^{18}}$

Dalam proses akad mudharabah, seperti halnya dalam proses muamalah lainnya tidak lepas dari ketentuan yang berkaitan dengan fiqih. Ketentuan fiqih yang paling utama berkaitan erat dengan implementasi mudharabah adalah rukun dan syarat mudharabah, hak 'amil/mudharib dalam menjalankan usaha serta masa berakhirnya mudharabah.

Madzhab Hanafi berpendapat, bahwa yang termasuk pada rukun mudharabah hanya ijab dan qabul, dengan lafazh yang menunjukkan kepada makna yang dimaksud. Sedangkan menurut madzhab Maliki, yang termasuk rukun adalah modal dan akad saja. Pendapat madzhab Asy-Syafi'i, yang termasuk pada rukun adalah pemilik dana/modal, modal, pengelola yang menjalankan usaha, keuntungan dan Akad (ucapan ijab qabul). Dan menurut madzhab Hambali, rukun mudharabah adalah adanya ijab dan qabul (akad). ${ }^{19}$

Menurut mayoritas ulama, ada tiga rukun dalam transaksi mudharabah yang harus dipenuhi; pertama, pelaku akad ('aqidayn) yaitu pemilik dana/modal (shahib al-maal) dan pengelola dana/modal ('amil/mudharib); kedua, ma'quud 'alaih yaitu modal (ra's al-maal), kemudian kerja (dharabah) dan laba (ribh); ketiga, ijab dan qabul (shighah). ${ }^{20}$

Menurut madzhab Hanafi, syarat mudharabah terdiri dari: 1). Modal usaha ialah mata uang emas atau perak menurut kesepakatan para pengikut madzhab, namun sah juga menggunakan uang konvensional; 2). Modal yang digunakan diketahui bersama ketika akad; 3). modal yang akan digunakan sudah ada di tangan pemilik dana/modal; 4). Dana diserahkan kepada pengelola untuk dikelola oleh dia sendiri; 5) Pengelola mendapat bagian tertentu yang bersifat umum; 6). Bagian bagi pengelola diambil dari keuntungan. ${ }^{21}$

Menurut madzhab Maliki, terdiri dari: 1). Menyerahkan modal kepada pengelola dengan segera; 2). Modal tersebut diketahui pasti pada waktu akad; 3). Modal bukanlah tanggungan dari pengelola. 4).Modal merupakan benda berharga yang biasa digunakan dalam bertransaksi; 5). Menjelaskan bagian khusus pengelola dari keuntungan; 6). Salah seorang dari kedua belah pihak tidak boleh dikkhususkan dengan bagian tertentu selain bagiannya sendiri; 7). Bagian tertentu dari keuntungan bersifat umum seperti setengah, sepertiga dan lain sebagainya; 8). Menjalankan usaha itu dikhususkan bagi pengelola; 9). Tidak ada unsur pemaksaan bagi pengelola dalam pengelolaannya; 10). Mudharabah tidak dibatasi dengan waktu.

\footnotetext{
${ }^{18}$ Rachmat Syafe'i, Fiqih Muamalah, (Bandung: Pustaka Setia, 2001), 226.

${ }^{19}$ Syaikh Abdurrahman Al-Juzairi, Fikih Empat Madzhab, Jilid 4, (Jakarta: Pustaka Al-kautsar, 2015), h. $56-68$

${ }^{20}$ Wahbah Az-Zuhaili, Fiqih Islam Wa Adillatuhu, Jilid 5 (Jakarta: Gema Insani, 2011), 479.

${ }^{21}$ Syaikh Abdurrahman Al-Juzairi, Fikih Empat Madzhab, Jilid 4, (Jakarta: Pustaka Al-kautsar, 2015), h. $56-68$
} 
Menurut madzhab Asy-Syafi'i, syarat mudharabah terdiri dari: 1). Pengelola dan pemilik dana/modal disyaratkan keduanya layak untuk melakukan akad; 2). Pengelolaan itu merupakan serangkaian kerja dalam usaha dagang yaitu jual dan beli; 3). Pengelola harus bebas dalam melakukan pengelolaannya; 4). Pengelolaan tidak boleh dibatasi dengan waktu tertentu; 5). Keuntungan dikhususkan untuk kedua belah pihak yang berakad; 6). Keuntungan ditetapkan dengan bagian tertentu seperti setengah, sepertiga dan lain sebagainya; 7). Menggunakan uang resmi; 8). Modal diketahui jumlah dan jenisnya; 9). Modal ditentukan secara pasti

Menurut madzhab Hambali, syarat mudharabah terdiri dari: 1). Menjelaskan bagian pengelola seperti setengah, sepertiga atau yang lainnya; 2). Jumlah modal dipastikan harus diketahui nilainya dengan jelas; 3). Dana/modal sudah harus tersedia; 4). Modal yang digunakan berupa nilai mata uang resmi dari pemerintah; 5). Bagian dari masing-masing kedua belah pihak bersifat umum.

Menurut Akhmad Farroh Hasan, Syarat yang harus ada dalam akad mudharabah terdiri dari: (1) Syarat 'aqidayn, yaitu orang yang akan melakukan akad (shahib al-maal dan 'amil/mudharib) harus cakap hukum (takwiil) atau ahli dalam mewakilkan (wakaalah); (2) Syarat modal (ra's al-maal), yaitu modal harus berupa mata uang (nuquud) yang berlaku dalam muamalah, besarnya modal harus mempunyai ukuran dan diketahui dengan pasti, modal bukan dalam bentuk utang tapi harus ada serta modal diserahkan kepada mudharib; (3) Syarat laba atau keuntungan (ribh), yaitu laba/keuntungan dapat diketahui ukurannya dan pembagiannya harus berdasarkan kesepakatan dari kedua pihak disesuaikan dengan kondisi pada umumnya yang berlaku pada saat itu. ${ }^{22}$

Pengertian akad, kata asalnya dalam bahasa Arab adalah dari kata 'Aqada artinya mengikat. Akad yang berarti perikatan antara penawaran (ijab) dengan penerimaan (qabul) dengan cara sesuai syara' yang berdampak pada timbulnya akibat-akibat hukum. Artinya dengan adanya akad, maka semua pihak yang terkait akan terikat oleh ketentuan syari'at yaitu adanya hak dan kewajiban yang harus dipenuhi. Syah atau tidaknya sebuah hukum pada sistem ekonomi sangat tergantung pada akad yang terjadi, yang artinya bahwa akad tersebut menjadi tolak ukur bagi keabsahan sebuah hukum.

Hasbi Ash-shiddieqi, membagi akad berdasarkan jenisnya ke dalam dua bagian, yaitu; 1). Akad-akad yang ditetapkan hukum-hukum tertentu dan diberikan namanya oleh syara' yang disebut dengan uqudun musammatun, diantaranya jual beli dan mudharabah; 2). Akad yang tidak ditetapkan hukum-hukum tertentu dan tidak diberikan namanya secara tertentu, yang disebut dengan uqudun ghairu musammatun, dimana akad seperti ini akan terus tumbuh di masyarakat seiring dengan perkembangan dan perubahan masyarakat, seperti akad di di asuransi, akad di perbankan, dan lainnya. Begitu juga akad

22 Akhmad Farroh Hasan, Fiqh Muammalah dari Klasik hingga Kontemporer (Teori dan Praktik), (Malang: UIN-Maliki Press, 2018), hlm.109-110. 
dibagi menjadi dua, bila dilihat dari segi tujuan dari akad tersebut; 1). Akad Tijari, yaitu akad yang beorientasi pada hasil/laba (profit oriented), seperti akad jual beli, mudharabah, sewa menyewa (ijarah); 2). Akad Tabarru, yaitu akad kebajikan yang bersifat ta'awun (tolong menolong) yang hanya berharap pada keridhaan Allah swt., seperti hibah, wakaf, atau pinjaman (qardh) ${ }^{23}$.

Berdasarkan pembagian tersebut, maka akad mudharabah termasuk pada uqudun musammatun yaitu akad yang sudah dikenal namanya dan ditetapkan hukumnya, dan dari segi tujuannya termasuk pada Akad Tijari yaitu akad yang berorientasi pada hasil/laba, sehingga mudharabah ini dapat menghidupkan perekonomian masyarakat dan mensejahterakan pihak-pihak yang berakad.

Kedudukan hukum mudharabah menurut pendapat para ulama madzhab ${ }^{24}$

Ulama madzhab Hanafi, berpendapat bahwa hukum mudharabah itu terbagi kepada beberapa macam, antara lain: Pertama, ketika pengelola sudah memegang dana dan belum memulai usahanya kedudukannya sebagai amiin (yang dititipi amanat). Kedua, ketika pengelola mulai menjalankan usahanya kedudukannya sebagai wakil, dan hukum wakil ialah sebagai pengganti dari orang yang diwakilinya. Ketiga, ketika mendapatkan untung kedudukan pengelola sebagai rekan usaha, sehingga dalam hal ini masing-masing pihak mendapat bagian tertentu dari keuntungan yang dihasilkan dari pengelolaan modal. Keempat jika akad mudharabah rusak kedudukan pengelola seperti orang yang mendapat upah, dalam arti semua keuntungan merupakan milik pemberi modal dan jika rugi pun menjadi tanggungannya sedang pengelola mendapat upah yang sebanding. Kelima; apabila pengelola menyalahi salah satu syarat maka dia dianggap sebagai perampas, dan hukum bagi perampas ialah dianggap sebagai pendosa, wajib baginya untuk mengembalikan rampasannya dan menanggung akibatnya. Keenam; jika disyaratakan semua keuntungan milik dari pengelola maka akad itu menjadi qardh. Ketujuh; apabila disyaratkan seluruh keuntungan untuk pemilik dana/modal maka hukumnya seperti hukum akad bidha'ah (barang komoditi) yaitu mewakilkan kepada orang untuk pembelian bidha'ah tanpa upah.

Ulama madzhab Hambali, hukum mudharabah bisa berbeda-beda tergantung kondisi: Pertama, mudharabah termasuk amanat dan wakalah (perwakilan), karena pengelola bertindak sesuai izin dari pemilik dana/modal; Kedua, jika pengelola mendapat keuntungan adalah akad mudharabah seperti syirkah (milik bersama) karena sama-sama kedua belah pihak mendapat keuntungan; Ketiga apabila mudharabah akadnya rusak ia

${ }^{23}$ Neneng Nurhasanah, Optimalisasi Peran Mudharabah Sebagai Salah Satu Akad Kerjasama Dalam Pengembangan Ekonomi Syari'ah. FH.UNISBA. VOL. XII. NO. 3 November 2010

${ }^{24}$ Syaikh Abdurrahman Al-Juzairi, Fikih Empat Madzhab, Jilid 4, (Jakarta: Pustaka Al-kautsar, 2015), hlm.56-68 
menjadi ijarah karena pengelola mengambil upahnya yang sesuai; Keempat apabila pengelola menyalahi perintah pemilik dana/modal, akadnya menjadi gashab (perampasan).

Islam sangat adil dalam menempatkan segala sesuatu, akad mudharabah dan akad musyarakah bernilai sangat positif, karena di dalamnya terkandung nilai kesamaan yang adil di antara mereka yang memiliki modal dan yang mengelola usaha, mereka bertanggungjawab dan berani dalam mengambil resiko. Islam tidak memihak kepada pemilik dana/modal dengan mengesampingkan pengusaha, begitu juga Islam tidak berpihak kepada kepentingan pengusaha dan mengesampingkan pemilik dana/modal (Yusuf Al Qardhawi, $2000: 52)^{25}$.

Adapun cara pembagian keuntungan atau tandiid, merupakan bagian dari rukun akad mudharabah yang sangat khas, karena memiliki perbedaan dengan akad yang lain. Rasio persentase (nisbah) adalah bagian yang akan diterima oleh para pihak yang berakad, yang penetapannya dicantumkan di dalam akad (perjanjian) dan disepakati diawal perjanjian. Kekhasan dalam pembagian keuntungan ini tidak ditetapkan secara mutlak besaran yang akan didapat oleh masing-masing pihak, dalam proses pembagian keuntungan bisa jadi terjadi tawar menawar dan negosiasi. Dalam membagi keuntungan tidak diperbolehkan untuk menentukan suatu jumlah yang tetap dan menentukan pembagian keuntungan berdasarkan modal, tetapi diperkenankan untuk menentukan nisbah yang tidak sama besarannya untuk keadaan atau proyek yang juga tidak sama. Misalnya nisbah yang akan diterima oleh pengelola sebesar $40 \%$ untuk usaha perdagangan, sedangkan nisbah jika usaha di bidang produksi menerima 50\%.

Semua ulama madzhab sepakat bahwa mudharib tidak diperkenankan untuk mendapat fee apalagi gaji tetap sebagai imbalan atas kerjanya dalam mengelola usaha tersebut, namun Imam Ahmad telah membolehkan apabila mudharib melakukan perjalanan usaha keluar kota dapat menuntut biaya akomodasi dalam memenuhi keperluan sehariharinya.

Apabila dalam satu usaha mengalami kerugian, tetapi mendapat hasil/laba dari usaha yang lain, maka hasil/laba tersebut digunakan untuk mengkompensasi kerugian yang terjadi, dan jika ada sisanya baru dibagikan kepada para pihak sesuai dengan proporsinya. Pembagian keuntungan umumnya dilaksanakan setelah pengelola dana/ modal ('amil/mudharib) memberikan sebagian maupun seluruh modal kepada pemilik dana/modal (shahib al-maal), tetapi tidak menutup kemungkinan untuk membagi keuntungan tanpa mengembaikan modal selama kerjasama mudharabah masih berlangsung. Nisbah hasil/laba bisa disepakati untuk dikaji kembali dalam setiap periode apabila jangka waktu akad mudharabah relatif lama. Apabila keuntungan ditentukan atas

${ }^{25}$ Neneng Nurhasanah, Optimalisasi Peran Mudharabah Sebagai Salah Satu Akad Kerjasama Dalam Pengembangan Ekonomi Syari'ah. FH.UNISBA. VOL. XII. NO. 3 November 2010 
dasar laba kotor (gross profit), maka semua biaya yang harus dikeluarkan disepakati bersama karena akan mempengaruhi nilai keuntungan.

Menurut madzhab Hanafi, mengatakan bahwa pembagian hasi/laba hanya sah setelah pemilik dana/modal mendapatkan modalnya terlebih dahulu. Apabila keuntungan sudah dibagi sebelum itu dan masih terdapat sisa pembagian, maka dianggap sah jika pemilik dana/modal mengambil modalnya. Namun jika tidak maka pembagian tadi telah batal.

Menurut madzhab Asy-Syafi'i, bahwa pembagian keuntungan sebelum diserahkan modal adalah sah kecuali jika keuntungan sudah dibagi sebelum barang dagangan semuanya telah terjual atau sebelum modal kembali menjadi bentuk uang.

Menurut madzhab Maliki, mengatakan bahwa kaidah yang berlaku dalam hal ini sangat menentukan. Jika usaha mudharabah merugi, atau modal rusak karena terkena hujan, atau dicuri, maka kerugian menarik keuntungan, dalam arti sisa dari kerugian dilengkapi dahulu dengan keuntungan. Jika ada dana berlebih maka kelebihan dana tersebut dibagikan kepada pemilik dana/modal dan pengelola sesuai dengan yang disyaratkan berdua. Apabila keuntungan telah dibagi sebelum modal dikembalikan, menurut kaidah, keuntungan tersebut harus dikembalikan, dan diharuskan menutupi modal terlebih dahulu jika kondisinya merugi.

Menurut madzhab Hambali, bahwa pengelola tidak berhak sedikitpun dari keuntungan hingga modal telah diserahkan kepada pemiliknya dan kerugian telah ditutupi dengan keuntungan. Jika pengelola membeli barang dagangan dan mendapat keuntungan dari penjualannya kemudian dia membeli barang dagangan yang lain, lalu merugi. Maka hasil keuntungan digunakan terlebih dahulu untuk menutupi kerugian dan tidak dianggap kerugian itu termasuk modal.

Ada beberapa cara yang bisa dilakukan dalam metode penghitungan laba, diantaranya: Pertama, al-tandiid al-haqiiqi, yaitu manifestasi basis likuidasi kekayaan mudharabah secara aktual; kedua, al-tandiid al-hukmi, yaitu dasar konstruktif sesuai metode pengakuan profit/laba yang dapat diterima atau penilaian independen berdasarkan perkiraan angka. Pengakuan keuntungan berdasarkan metode konstruktif; Pertmaa, dapat dibuat cadangan keuntungan; kedua, pada akhir periode tertentu dilakukan konsolidasi dan penyesuaian akhir. ${ }^{26}$

Akad mudharabah berakhir kalau tujuan dari kerjasama tersebut sudah tercapai, dan akad mudharabah dapat dinyatakan selesai atau batal, jika: (1). Kedua belah pihak mengatakan akad batal atau berakhir, dalam hal ini mudharib tidak diperkenankan bertindak hukum atas modal, atau pemilik dana/modal (shahib al-maal) mengambil kembali dananya; (2). Salah satu diantara 'aqidayn wafat; (3). Salah seorang dari 'aqidayn

26 Sofian Al hakim, Dinamika Fatwa Mudharabah dan Murabahah di Indonesia dan Malaysia, (Bandung: Pusat Penelitian dan Penerbitan UIN Sunan Gunung Djati Bandung, 2019), hlm.185 
hilang ingatan/gila; (4). Menurut Abu Hanifah akad mudharabah batal apabila pemilik dana/modal murtad; (5). Jika dana/modal habis digunakan oleh pemilik dana/modal (shahib al-maal) dan tidak ada yang dapat dikelola lagi oleh mudharib; (6). Terjadi pelanggaran atas syarat-syarat tertentu (mukhaslafah al-shuruut), atau adanya kelalaian (taqsiir) atau terjadi pelanggaran oleh salah satu pihak (ta'addi), sehingga dilakukan pemutusan sepihak; (7). Sesuai kesepakatan berakhirnya kontrak karena jatuh tempo; (8). Demise atau pembubaran Shahib al-maal atau mudharib atau kehilangan kapasitas hukum; (9). Ketidakabsahan mudharabah. ${ }^{27}$

Pada umumnya mudharabah terbagi pada dua jenis: Pertama, mudharabah bebas (al-mudharabah al-Muthlaqah) yaitu pemilik dana/modal (shahib al-maal) membebaskan pengelola dana/modal ('amil/mudharib) untuk menentukan sendiri mengenai jenis usaha, waktu, tempat dan dengan siapa melakukan transaksi. Dalam mudharabah al-Muthlaqah ini pengelola ('amil/mudharib) mempunyai keleluasaan dalam berusaha dan memiliki wewenang untuk bertindak apa saja yang dibutuhkan guna mencapai keberhasilan tujuan mudharabah, tetapi kebebasan ini bukannya kebebasan tak terbatas sama sekali karena modal yang ditanamkan tidak boleh digunakan untuk hal-hal yang tidak diperbolehkan oleh agama maupun yang dilarang oleh peraturan perundang-undangan negara;

Kedua, Mudharabah terbatas (al-mudharabah al-Muqayyadah) yaitu pemilik dana/ modal (shahib al-maal) memberikan dananya kepada pengelola ('amil/mudharib) dengan memberikan ketentuan atau batasan mengenai jenis usaha atau waktu atau tempat atau dengan siapa pengelola dana/modal ('amil/mudharib) bertransaksi. Dalam hal ini pengelola dana/modal ('amil/mudharib) tidak memiliki kebebasan dalam menggunakan dana tersebut, tetapi harus memeuhi syarat-syarat yang ditentukan oleh pemilik dana/modal (shahib al-maal). Jika dalam mudharabah tersebut dibatasi waktunya, maka apabila sudah waktunya tiba secara otomatis mudharabah tersebut berakhir.

Kewajiban utama dari seorang pemilik dana/modal (shahib al-maal) adalah menyerahkan dana/modal kepada pengelola dana/modal ('amil/mudharib) untuk tujuan membiayai suatu kegiatan usaha atau proyek, dan apabila hal ini tidak terjadi, maka perjanjian mudharabah dinyatakan tidak sah.

Pemilik dana/modal (shahib al-maal) tidak diperbolehkan untuk ikut mengelola kegiatan usaha atau proyek yang dibiayainya, pemilik dana/modal (shahib al-maal) hanya diperkenankan memberikan masukan-masukan tertentu kepada pengelola dana/modal ('amil/mudharib) dalam melaksanakan usaha tersebut. Dengan demikian pemilik dana/modal (shahib al-maal) hanya memiliki hak untuk mengawasi guna memastikan bahwa pengelola dana/modal ('amil/mudharib) mentaati semua persyaratan dan segala ketentuan yang tercantum dalam perjanjian. Pemilik dana/modal (shahib al-maal) berhak memperoleh kembali modalnya dan sekaligus keuntungannya apabila usaha mudharabah

${ }^{27}$ ibid, hlm.187 
telah selesai dan hasil usaha mudharabah itu cukup untuk mengembalikan modal dan membagi keuntungan.

Tanggung jawab pemilik dana/modal (shahib al-maal) dalam akad mudharabah hanya sebatas pada modal yang dia tanamkan. Asas seperti ini sangat penting dalam perjanjian mudharabah, karena apabila asas ini tidak ada maka tanggung jawab pemilik dana/modal (shahib al-maal) menjadi tidak terbatas dan tidak jelas.

Bagi seorang pengelola dana/modal ('amil/mudharib), terdapat tiga jenis aktivitas atas dana/modal mudharabah: Pertama, aktivitas yang boleh dilaksanakan atas dasar kontrak; kedua, aktivitas yang boleh dilaksanakan atas dasar kekuasaan; dan ketiga, aktivitas yang tidak boleh dilaksanakan tanpa izin dari pemilik dana/modal.

Pengelola dana/modal ('amil/mudharib) memiliki wewenang atau kekuasaan untuk dapat bertindak secara leluasa mengelola modal dalam kegiatan usaha untuk dapat mencapai semua tujuan dari perjanjian mudharabah, yaitu untuk mendapat hasil/laba dari bisnis yang dijalankannya, selama apa yang dilakukannya tidak menyalahi perjanjian dan melanggar aturan yang ditetapkan syari'ah atau bertentangan dengan perturan perundang-undangan negara.

Tanggung jawab pengelola dana/modal ('amil/mudharib) hanya sebatas mencurahkan pikiran, waktu dan jerih payah untuk menanggulangi perkara yang berhubungan dengan kegiatan usaha atau proyek yang didanai dengan pembiayaan mudharabah. Pengelola dana/modal ('amil/mudharib) tidak bertangungjawab atas habisnya atau berkurangnya modal dari pemilik dana/modal (shahibul maal).

Akad mudharabah merupakan akad yang timbul dari kepercayaan (trust), sehingga dengan berbekal kepercayaan inilah sebagian ulama tidak memperkenankan kepada pemilik dana/modal untuk meminta jaminan kepada pengelola, sebagaimana jaminan yang diberlakukan dalam akad utang piutang. Tetapi sebagian ulama lain membolehkan pemilik dana/modal untuk meminta jaminan kepada pengelola atau kepada pihak ketiga sebagai agunan resiko.

Diperbolehkannya meminta jaminan kepada pengelola dana/modal, sebagai antisipasi jika terjadi pelanggaran atau melalaikan ketentuan yang sudah disepakati bersama yang dilakukan oleh si pengelola dana/modal, jaminan ini disebut dengan istilah jaminan khianat (moral hazard).

Yang menjadi argumentasi sehingga di perbankan syari'ah diperkenankan untuk meminta jaminan pada saat melakukan transaksi mudharabah adalah sebagai berikut: Pertama, Pihak Bank atau pemilik dana/modal tidak mengetahui bagaimana kredibilitas maupun kapabilitas dari para pengguna dana (mudharib) yang melakukan transaksi mudharabah dengan pihak bank. Tidak seperti halnya praktik mudharabah pada zaman nabi, yang hanya sedikit sehingga dapat diketahui dengan pasti. Kedua, Keadaan masyarakat pada umumnya yang cenderung mengalami perubahan, sehingga alasan (illat) 
terhadap nilai-nilai kepercayaan tidak perlunya ada jaminan, mengalami perubahan sebagai halnya kaidah, bahwa keberadaan illat dapat menentukan keberadaan hukum. Ketiga, Jaminan terkait dengan akibat atas pelanggaran, kelalaian, dan penyalahgunaan ketentuan yang sudah disepakati. Hal tersebut diakui dalam Fatwa DSN-MUI No. 07/DSNMUI/IV/200o tentang Pembiayaan Mudharabah (Qiradh) Fatwa DSN-MUI No 115/DSNMUI/IX/2017 tentang Mudharabah.

\section{Implementasi Mudharabah Dalam Industri Keuangan Syari'ah}

Implementasi mudharabah di lembaga keuangan syaria'ah, menjadi salah satu instrumen pengganti instrumen bunga. Implementasi mudharabah dilembaga keuangan syari'ah tentunya memiliki spesifikasi yang tidak sama antara yang satu dengan lembaga keuangan syari'ah yang lainnya. Lembaga Keuangan Syari'ah yang mengimplementasikan mudharabah, diantaranya adalah: 1) Perbankan Syari'ah dan BMT, 2) Asuransi Syari'ah, 3) Reksadana Syari'ah, 4) Pasar Modal Syari'ah, 5) Surat Berharga Syari'ah Negara (SBSN)/ Sukuk.

Tujuan utama Bank adalah mendapatkan keuntungan, sehinga dalam hal ini Bank Syari'ah dapat berperan dalam mendapatkan keuntungan dengan memberikan kemudahan untuk jenis usaha produksi dan infestasi kepada kelompok menengah ke bawah. Salah satu cara dalam meraih keuntungan tanpa memberlakukan instrumen bunga adalah dengan akad mudharabah. Akad mudharabah ini biasanya diterapkan dalam produk pendanaan maupun pembiayaan.

Perbankan syari'ah menerapkan akad mudharabah pada sektor: ${ }^{28}$ 1) Tabungan berjangka; 2) Deposito spesial (special investment); 3) Pembiayaan modal kerja; dan 4) Investasi khusus.

Produk utama pada bank syari'ah yaitu berupa penghimpunan dana atau simpanan dan penyaluran dana atau pembiayaan dan juga ditunjang dengan produk jasa lainnya. Instrumen mudharabah oleh bank syari'ah di aplikasikan pada dua produk utama tersebut, yaitu pada produk penghimpunan dana dan produk penyaluran dana atau pembiayaan. Pada saat bank menghadapi nasabah penabung, maka bank akan berperan sebagai mudharib, tetapi pada saat menghadapi nasabah pembiayaan, maka bank akan berperan menjadi shaahib al-maal (pemilik dana/modal). ${ }^{29}$

\section{Simpulan}

Berdasarkan uraian diatas dapat penulis simpulkan, bahwa Mudharabah merupakan suatu bentuk kerjasama antara pemilik dana/modal (shahib al-maal) dengan pengelola

${ }^{28}$ Sri Sudiarti, Fiqh Muamalah Kontemporer, (Medan: FEBI UIN-SU Press, 2018), hlm. 165

29 Sofian Al hakim, Dinamika Fatwa Mudharabah dan Murabahah di Indonesia dan Malaysia, (Bandung: Pusat Penelitian dan Penerbitan UIN Sunan Gunung Djati Bandung, 2019), hlm. 191 
dana/modal (mudharib) untuk melakukan usaha tertentu dengan pembagian keuntungan yang adil atas dasar nisbah. Mudharabah yang merupakan salah satu akad percampuran sangat dianjurkan dalam Islam untuk diimplementasikan dalam kehidupan masyarakat, mudharabah dapat membantu mempersatukan antara seseorang yang memiliki kelebihan harta dengan seseorang yang sebaliknya tidak memiliki harta tetapi memiliki keahlian dalam bidang usaha, sehingga dapat saling mensejahterakan diantara mereka berdua. Akad mudharabah merupakan akad yang bernilai positif, antara pemilik dana/modal dan pengelola memiliki kedudukan yang sama, sama-sama bertanggung jawab dan samasama berani dalam memikul resiko, adil dan seimbang dalam semua aspek. Mudharabah sebagai salah satu instrumen pada lembaga keuangan syari'ah, diimplementasikan di lembaga keuangan syari'ah, seperti perbankan, BMT, asuransi, reksadana, pasar modal dan Surat Berharga Syari'ah Negara (SBSN)/Sukuk yang diterapkan dalam produk pendanaan (tabungan dan deposito) dan pembiayaan (pembiayaan modal kerja dan investasi khusus).

\section{Daftar Pustaka}

Al hakim, Sofian. Dinamika Fatwa Mudharabah dan Murabahah di Indonesia dan Malaysia, Bandung: Pusat Penelitian dan Penerbitan UIN Sunan Gunung Djati Bandung. 2019.

Al-Juzairi Syaikh Abdurrahman. Fikih Empat Madzhab, Jilid 4, Jakarta: Pustaka Al-Kautsar. 2015.

Antonio, Muhammad Syafi'i. Bank Syariah: Dari Teori ke Praktik. Jakarta: Gema Insani Pers. 2001.

Az-Zuhaili, Wahbah. Fiqih Islam Wa Adillatuhu, Jilid 5, Jakarta: Gema Insani. 2011

Dewi, Gemala. Aspek-aspek Hukum dalam Perbankan dan Perasuransian Syariah di Indonesia, Edisi Revisi. Cet. ke-3, Kencana Prenada Media. 2006.

Fatwa Dewan Syariah Nasional-Majelis Ulama Indonesia No: 115/DSN-MUI/IX/2017 tentang Akad Mudharabah.

Hasan, Akhmad Farroh. Figh Muammalah dari Klasik hingga Kontemporer (Teori dan Praktik), Malang: UIN-Maliki Press. 2018.

https://idoc.pub/documents/ diakses tanggal o4 Mei 2020

https://kbbi.web.id/perspektif diakses tanggal 04 Mei 2020

Janwari, Yadi. Lembaga Keuangan Syari'ah. Bandung: PT. Remaja Rosdakarya. 2015

Karim, Adiwarman. Bank Islam Analisis Figh dan Kevangan, Jakarta: The International Institut Of Islamic Thought (IIIT). 2003 
Asep Dadang Hidayat dan Mohammad Sar'an, Akad Mudharabah sebagai Instrumen Pendanaan ...| 235

Karim, Adiwarman. Ekonomi Islam Suatu Kajian Kontemporer. Jakarta: Gema Insani. 2001.

Karim, Helmi. Fiqih Mu'amalah. Jakarta: PT Raja Grafindo Persada. 1993.

Kompilasi Hukum Ekonomi Syariah

Masse, Rahman Ambo. Konsep Mudharabah Antara Kajian Figh dan Penerapan Perbankan, Jurnal Hukum Diktum, Volume 8 (1), Januari 2010

Muhammad. Sistem dan Prosedur Operasional Bank Syari'ah, Yogyakarta: UII Press. 2000.

Muhammad. Teknik Bagi Hasil Keuntungan pada Bank Syari'ah, Yogyakarta: UII Press. 2004 .

Nazir, M. Metode Penelitian, Jakarta: Ghalia Indonesia. 1983

Nurhasanah, Neneng. Mudharabah dalam Teori dan Praktik, Bandung: PT Refika Aditama. 2015.

- Optimalisasi Peran Mudharabah Sebagai Salah Satu Akad Kerjasama Dalam Pengembangan Ekonomi Syari'ah. Jurnal FH.UNISBA. VOL.XII, No.3, November 2010.

Sayyid, Sabiq. Fikih Sunnah, Jilid 14. Cet. 9, Bandung: Al-Ma'arif, 1997.

Sudiarti, Sri. Fiqh Muamalah Kontemporer, Medan: FEBI UIN-SU Press, 2018.

Sugiyono. Metode Penelitian Kuantitatif kualitatif dan R\&D, Bandung: Alfabeta. 2008.

Syafei, Rahmat. Fiqih Muamalah. Bandung: CV Pustaka Setia. 2001. 
236 | Asy-Syari'ah Vol. 22 No.2, Desember 2020

[Halaman ini sengaja dikosongkan] 
Asy-Syari'ah (P-ISSN: 2086-9029 E-ISSN: 2654-5675) is a periodical scientific journal that publishes various results of studies and research, literature review, and other scientific works whose scope covers the field of Islamic law/sharia, law and society in monodisciplinary, interdisciplinary, and multidisciplinary manners. The journal aims to expand and create innovative concepts, theories, paradigms, perspectives and methodologies in the above said scope. The Journal is published twice a year (june and december) by Faculty of Shariah and Law, Sunan Gunung Djati State Islamic University Bandung in collaboration with Asosiasi Sarjana Syariah Indonesia (ASSYI).

\section{EDITORIAL OFFICE:}

Fakultas Syariah dan Hukum UIN Sunan Gunung Djati Bandung J1. Raya A.H. Nasution No. 105 Cibiru Kota Bandung, 40614

Tlp/Fax: +022-7802278 Faks. 022-7802278

Website http://journal.uinsgd.ac.id/index.php/asy-syariah/index

E-mail: Jurnalasy-syariah@uinsgd.ac.id 